January 2010

\title{
Willing to Work: Agency and Vulnerability in an Undocumented Immigrant Network
}

Ruth Gomberg-Munoz

Loyola University Chicago, rgombergmunoz@gmail.com

Follow this and additional works at: https://ecommons.luc.edu/social_justice

Part of the Social and Cultural Anthropology Commons

\section{Recommended Citation}

Gomberg-Munoz, Ruth, "Willing to Work: Agency and Vulnerability in an Undocumented Immigrant Network" (2010). Social Justice. 3.

https://ecommons.luc.edu/social_justice/3

This Article is brought to you for free and open access by the Centers at Loyola eCommons. It has been accepted for inclusion in Social Justice by an authorized administrator of Loyola eCommons. For more information, please contactecommons@luc.edu. 


\title{
Willing to Work: Agency and Vulnerability in an Undocumented Immigrant Network
}

Ruth Gomberg-Muñoz

\begin{abstract}
Restriction-oriented immigration policies and polarizing political debates have intensified the vulnerability of undocumented people in the United States, promoting their "willingness" to do low-wage, low-status work. In this article, I draw on ethnographic research with undocumented immigrants in Chicago to examine the everyday strategies that undocumented workers develop to mediate constraints and enhance their well-being. In particular, I explore how a cohort of undocumented Mexican immigrants cultivates a social identity as "hard workers" to promote their labor and bolster dignity and self-esteem. Much of the existing literature on unauthorized labor migration has focused on the structural conditions that encumber immigrants and constrain their opportunities. By shifting the focus to workers' agency, I seek to complement these analyses and show how undocumented immigrants actively navigate the terrain of work and society in the United States.
\end{abstract}

Keywords: undocumented immigrants, agency, labor migration, Mexican workers, service

RESUMEN La vulnerabilidad de los trabajadores indocumentados en los Estados Unidos ha sido incrementada por políticas inmigratorias restrictivas y debates políticos polarizados que han fomentando la "voluntad" de aceptar trabajos de bajo sueldo y estatus. En este artículo, utilizo investigaciones etnográficas con inmigrantes indocumentados en Chicago para examinar las luchas diarias que se enfrenta este grupo para mejorar sus calidades de vida. En particular, exploro como un grupo de inmigrantes indocumentados mexicanos cultiva una identidad social de "hombres trabajadores" para promover su mercado laboral, asi mejorando su bienestar económico y emocional. La mayoría de la literatura contemporánea sobre la migración indocumentada se ha enfocado en las condiciones estructurales que limitan a los inmigrantes y restringen sus oportunidades. Cambiar el enfoque hacia las acciones diarias de los trabajadores complementa estos estudios, y además demuestra la manera como los inmigrantes indocumentados activamente navegan sobre el terreno del trabajo y sociedad en los Estados Unidos.

\section{THE BUSBOY SHOW}

On weekend nights, when "Il Vino" (a large Chicago-area restaurant) is busy and the lounge is crowded with diners waiting for a table, five Mexican immigrant busboys get together to stock the bar. ${ }^{1}$ I call this "the Busboy Show." First, the busboys load about 20 cases of beer and two bins of liquor onto a wheeled cart. Then they push this cart through the restaurant to the service station at the bar. Two or three of them will stay on the outside of the bar with the cart, and the other two or three will go behind the bar. The bartenders and servers get out of the way. Like a sped-up assembly line, one busboy will snatch a case of beer from the cart and throw it-literally, throw into in the air — to a second busboy standing closer to the bar. This busboy catches it easily and tosses it across the top of the bar, where a busboy standing behind the bar grabs it and throws it to a fourth busboy, who catches it and stacks it in front of the beer coolers. A final busboy will rip open the cases and stock beer in the coolers. They work lightning quick - it only takes them about one minute to empty the cart. Customers and restaurant employees gather around to watch, commenting on the busboys' strength and speed. 
The busboys enjoy the attention and ham it up for onlookers, prodding each other to go faster and faster. They also try to outdo one another by throwing the cases as high into the air as they can. Sometimes, when there's a new busboy, the other guys will throw him an empty case just to laugh as he juggles it in the air.

The Mexican busboys at Il Vino have a reputation as "the hardest workers that we have," in the words of their supervisors and coworkers alike. This association of Mexican immigrants with hard work is not unique to Il Vino. ${ }^{2}$ In fact, the conception of Mexican immigrants as a laboring class has a long history in the United States, and for more than a century Mexican workers have often been considered a diligent, tractable segment of the U.S. work force (De Genova 2005; Gamio 1971; Gutierrez 1995; Heyman 2001). Ethnographic research shows that the perception of Mexican immigrants as hard workers continues to have popular currency (Coutin and Chock 1997; De Genova and Ramos Zayas 2003; Waldinger and Lichter 2003). In particular, many low-wage employers express their approval of Mexican immigrants' apparent willingness to do low-wage, low-status work (De Genova 2005; Neckerman and Kirschenman 1991; Waldinger and Lichter 2003). But where does this apparent willingness to work hard come from? And why would presumably permanent members of the low-wage labor force put so much effort into being hard workers?

Recent ethnographic scholarship by Nicholas De Genova (2005), Christian Zlolniski (2006), and Josiah Heyman (2001) has considered how undocumented immigrants' labor practices are circumscribed by the state but negotiated and transformed through the activities of workers, managers, and state agents themselves (see also Brodkin 2007 and Smith-Nonini 2007). For example, De Genova's 2005 work explores the ways in which Mexican workers grapple with racialization, "illegalization," and labor subordination in a Chicago factory, while Zlolniski's 2006 ethnography examines labor flexibility and organized resistance efforts among immigrant janitors in California. Building on these studies, I consider in this article how a cohort of undocumented Mexican immigrants negotiates a social identity as hard, willing workers as they promote their labor and cultivate dignity and self-esteem.

The purpose of this article is to provide an ethnographic description of workaday struggles that undocumented people wage to make their lives better - in light of serious constraint. I begin by briefly considering the interactions among culture, structure, and agency, in which undocumented immigrants respond to constraints by constructing certain norms and social identities, then I move on to ethnographic descriptions that show how and why a willingness to work hard is negotiated by undocumented workers on the restaurant floor. I particularly examine how workers establish norms of hard work discursively through teasing, peer pressure, and confrontation. Then I explore how behaviors that promote an ethic of hard work also give rise to contradictions among workers, as they struggle to reconcile their vulnerabilities with ideals of autonomy and bravery. Ultimately, I hope to show how categorical inequalities are simultaneously reproduced and resisted in the everyday activities of undocumented people, with both short-term and long-term implications.

An attention to the workaday activities of undocumented immigrants complements existing literature on unauthorized labor migration that has tended to focus on macrolevel processes rather than microlevel lives (e.g., Heyman 1998; Kearney 2004; Massey et al. 1994; Massey et al. 2002; Ngai 2005; Portes and Walton 1981; Sassen 1988; but see Chavez 1992; Zlolniski 2006). By focusing on workers' agency, this research also advances scholarship that has criticized political-economic approaches to globalization and migration for being overly deterministic and "top down” (Basch et al. 1994; Fernandez-Kelly 1983; Mahler 1998). But an analysis of the interaction of agency and constraint avoids obscurantist treatments of local identity making that can mask implications of unequal power structures (see also Bourgois 2003; di Leonardo 1998; Durrenberger and Erem 2005). More broadly, as I examine how categorical inequalities are perpetuated and resisted in the everyday lives of marginalized workers, I hope to contribute, if only modestly, to anthropological theories of social reproduction and change. Finally, by focusing attention on the everyday lived realities of undocumented people, I seek to push past one-dimensional stereotypes of "illegal immigrants" as mere victims or criminal usurpers and emphasize their complex humanity.

\section{"SOMETHING IS INSTILLED IN THEM FROM BIRTH, I THINK": ON CULTURE, STRUCTURE, AND WORKERS' AGENCY}

The ethnographic focus of this article is a cohort of ten undocumented immigrant men: Alejandro, Alberto, Chuy, Lalo, Leonardo, Luis, Manuel, Omar, Rene, and Roberto. ${ }^{3}$ All of these men have worked as busboys in Chicago-area restaurants, and they all are members of the same transnational social network that moves between Chicago, Illinois, and León, Guanajuato, Mexico. ${ }^{4}$ These workers differ meaningfully in their beliefs, experiences, and plans for the future, but they also have important things in common. They are friends, and in some cases brothers and cousins, who share the stigma of being "illegal aliens" and the dignity of being hard workers and family men. In this article, I examine how these workers use their agency to create a culture of hard work that is responsive to their particular structural vulnerabilities. But how to best conceptualize the everyday interactions of culture, structure, and agency remains an enduring anthropological problem.

In popular discourse, Mexican immigrants' work ethic is often attributed to their "culture" or "cultural background" (Gutierrez 1995; Moss and Tilly 2001; Waldinger and Lichter 2003). Not only coworkers and managers at restaurants like Il Vino but also my colleagues at the university have 
suggested that the busboys' work ethic "may be just cultural." This popular use of culture identifies work ethic as an essential, integral component of Mexican society, as this comment from Il Vino's manager shows: "They are just phenomenal workers. I don't know what it's like in Mexico, but something happens there. Something is instilled in them from birth I think" (conversation with author, March 11, 2008). But the idea that there is "just something" about Mexican culture that produces hard workers glosses over variation among Mexican workers, ignores the role of inequality in structuring labor conditions, and diminishes workers' agency on the job. Relatedly, this folk use of culture overlooks the historical subordination of Mexican workers in the United States that has given rise to an association between Mexican immigrant workers and a "willingness" to work hard. For example, Mexican workers in the United States are typically relegated not only to low-wage, low-status jobs but also frequently to piece-rate work, temporary contract labor, or nonunionized employment in which income and job security are directly tied to the degree of "hard work" that a worker puts forth (see Gamio 1971; Zlolniski 2006). In the end, the notion that a "Mexican work ethic" is an integral part of "Mexican culture" essentializes Mexican immigrant workers, naturalizing their historical subordination and reducing their work performances to a putative cultural inclination for socially degraded, back-breaking labor (for critiques of this use of culture, see also di Leonardo 1998; Gershon and Taylor 2008).

While anthropological notions of "culture" usually avoid this kind of naturalization of inequality and difference, Arjun Appadurai (2004:60) notes that in an anthropological sense culture has typically referred to "one or other kind of pastness"- beliefs and behaviors that are presumably traditional, slow to change, and permanently present in a local, bounded social group. This notion of "culture" has been criticized for assuming distinctions between groups of people - and homogeny within them - that are, at best, amorphous and fluid (Appadurai 1996, 2004; Douglas 2004; but see Rosenblatt 2004). Further, traditional anthropological conceptions of culture may diminish the role of Western domination and expansion in the creation, differentiation, and study of putatively bounded cultural groups (Gupta and Ferguson 1997). In response, anthropologists have increasingly turned their attention to the ways in which shared meanings and social identities are continuously created and recreated in everyday interactions (e.g., Gershon and Taylor 2008; Rao and Walton 2004; see also Willis 1977). A conception of culture as "those differences that either express, or set the groundwork for, the mobilization of group identities" (Appadurai 1996:13) emphasizes the situational, dynamic construction of norms, boundaries, meanings, and group identities and the way that these take shape as part of broader economic and sociopolitical landscapes (Rao and Walton 2004; Sen 2004).

Insofar as cultural differences are continuously created and interpreted by human actors, human agency produces culture (Ortner 2006; Rosenblatt 2004). Culture, agency, and structures of power are mutually influencing: agency produces culture as agency is shaped and constrained by cultural norms and boundaries; both culture and agency can affect structures of unequal power, as agency is differentially empowered or limited by structure in turn (Giddens 1993; Ortner 1997, 2006; Sewell 1992). When the concept of "agency" is applied to undocumented immigrants, who are highly circumscribed in their choices and activities, the question arises as to whether these workers are actually exercising their agency or are merely doing what they must to survive. This latter interpretation suggests that the highly controlled environment in which undocumented immigrants live and work largely deprives them of meaningful choice and agency. ${ }^{5}$ But as Nandini Gunewardena and Ann Kingsolver (2007) note, while human agency represents power in a broad sense of capability for action, it is not reducible to empowerment. Rather, agency is the human capacity to exert some control over the conditions of one's existence; it is "the ability of people to affect their world" (Rosenblatt 2004:461; see also Giddens 1993; Ortner 1997, 2006; Sewell 1992). Inequality differentially constrains the scope and effectiveness of agency (Ortner 2006; Sewell 1992), such that this small group of undocumented workers is unlikely to impact U.S. immigration policy or even change their subordinate status at the restaurant. Nevertheless, as I will show, they can and do effectively shape their work environment through their collective agency. ${ }^{6}$

For example, when these workers throw cases of beer to each other (instead of simply and less spectacularly handing them off), they are achieving at least four interrelated effects. First, they are exerting control over how they are perceived by their white U.S. bosses, coworkers, and customers. This form of "impression management" (Goffman 1959) taps into U.S. folk culture notions of "Mexican work ethic," reinforcing an association of the Mexican staff with hard work and enhancing their job security at the restaurant. Second, they are cultivating norms of hard work amongst themselves, effectively creating a culture of work that shapes how each busboy approaches his work and perceives his labor. Third, they are responding to particular structural vulnerabilities - financial insecurity, racialization, and social stigmatization - and attempting to manage and reduce these vulnerabilities. Fourth, reproducing racialized stereotypes of "Mexican work ethic" can have the ultimate effect of reinforcing racial circumscription of the Mexican immigrant staff, an unintended but important outcome (see Tilly 1998 for a discussion of durable inequality).

Denying workers agency risks reducing them to mere pawns and diminishing their capacity to affect social life. Conversely, emphasizing agency at the expense of structure can mask political and economic realities and obscure relations of domination and subordination. A conception of "agency" as effective, but not necessarily empowered, human action allows us to understand the meaningful activity of disempowered, marginalized, and subjugated people who 
act on their own behalf (see, e.g., Bourgois 2003; Willis 1977; Zlolniski 2003, 2006). This conception of agency also resembles Karl Marx's well-known observation that "men make their own history, but not of their own free will; not under circumstances they themselves have chosen" (1973:146), which locates the prime mover of social reproduction and change in the activities of subordinated workers. The following sections explore in more detail how and why this group of undocumented workers exercises their collective agency to shape their relationships to work and society in the United States.

\section{"A LITTLE SOMETHING EXTRA": WILLINGNESS AS A SPECIAL FEATURE OF LABOR POWER}

As early as 1907, Mexican workers began migrating to Chicago in large numbers to work in the city's burgeoning rail yards (De Genova 2005:113). By the 1920s, Chicago had the largest population of Mexicans in the United States outside of the U.S. Southwest (Ready and BrownGort 2005), and Mexican workers constituted 43 percent of all railroad-track labor and 11 percent of employees in steel and meatpacking plants in the Chicago area (De Genova 2005:114). The concentration of these industries on Chicago's South Side led to the settlement of major Mexican communities in South Side neighborhoods. While the meatpacking plants, steel mills, and rail yards that initially attracted Mexican workers to Chicago are now largely defunct, well-established transnational networks and an expanding service economy have meant a steady increase in the Mexican immigrant population of Chicago's city and suburbs over the past four decades (Ready and Brown-Gort 2005).

In postindustrial "global cities" like Chicago, highly educated and highly skilled workers have flourished economically, boosting demand for workers in low-end service industries like hospitality and maintenance (Calavita 1994; Gray 2004; Hondagneu-Sotelo 1994; Lamphere et al. 1994; Sassen 1988; Smith-Nonini 2007). Most service work cannot be exported, and service is one of the few industries that actually experiences growth in postindustrial regions. The service economy currently accounts for two-thirds of jobs in developed nations, and work in construction, maintenance, and hospitality is quickly overtaking manufacturing as the most important source of employment for low-skill workers in urban centers (Castells 2000; Massey et al. 1994; Smith-Nonini 2007:199).

This has important implications for conditions of labor, as low-end service workers are often less constrained by mechanization and, largely lacking union protection, are highly vulnerable to repressive work conditions and low wages (Sassen-Koob 1981; Smith-Nonini 2007). The expansion of service economies also has important implications for the characteristics of workers themselves because the attractiveness of service labor power is often evaluated on subjective criteria such as work ethic and good attitude, behaviors that are in turn promoted by conditions of vulnerability and powerlessness (Moss and Tilly 2001; Sassen-Koob
1981; Waldinger and Lichter 2003; Zlolniski 2006). Being particularly powerless, undocumented immigrants make especially desirable service workers (Sassen-Koob 1981), and they comprise over 10 percent of the U.S. work force in lowend service industries such as construction labor (25 percent), groundskeeping and building maintenance (19 percent), and leisure and hospitality (17 percent), even though they account for only 5.4 percent of the total civilian labor force (Passel 2006; Passel and Cohn 2009).

Characteristics of the service economy and its work force are not givens but, rather, are continuously created through state activities and everyday interactions between workers and managers (Gray 2004; Zlolniski 2003; see Gibson-Graham 1996 for a critique of the "essentialization" of capitalism). As Mia Gray (2004) points out, there is nothing inherent to the service sector that renders some jobs high paying and others low paying. Rather, low wages in the service sector are the function of a confluence of factors, including the following: lack of unionization, social degradation of low-end service sector jobs, and policies that undermine organization efforts and differentiate sectors of the service labor force by race, gender, and immigration status (Fernandez-Kelly 1983; Fine 1996; Gray 2004; Heyman 2001; Kearney 2004; Stepick and Grenier 1994). Relatedly, as Zlolniski $(2003,2006)$ argues, the labor flexibility of immigrant workers is not an intrinsic characteristic but, rather, is continuously negotiated and challenged in interactions between managers and workers.

At restaurants like Il Vino, racialized immigration categories and work categories are mapped onto one another, and Mexican immigrants are segregated into the lowest-paid jobs: typically as busboys, line cooks, and dishwashers (see also Adler 2005; Fine 1996; Stepick and Grenier 1994). A willingness to be diligent and tractable is expected from the Mexican immigrant workers in these jobs; it is an essential feature of their labor. This comment from Julia, the general manager at Il Vino, represents management's perspective on the flexibility of the immigrant bus staff: "I think that we just look at them as busboys and they will do really whatever you ask them to do. From garbages to cleaning out toilets toyou know. So I think we're harder on them in that we take it for granted ... and expect that they will do whatever we ask them to do" (conversation with author, March 11, 2008). This sentiment is echoed by other supervisors at restaurants in Chicago, who identify Mexican immigrants' willingness to do "whatever we ask" as an important component of their labor.

Extra work and flexible work have become part of the everyday routine for the Mexican immigrant busboys at Il Vino, resulting in an increased and diversified workload. On a regular work day, busboys serve water and bread, help servers carry food trays, put leftovers in carryout containers, clear tables of dirty dishes, and "turn over" tables when diners leave (removing dirty linens, dishes, and silverware and replacing them with clean ones). Each busboy is typically responsible for his own section. Sections can vary in size, 
but at Il Vino each busboy section is usually comprised of three smaller sections that each have one server and five four-person tables. In other words, on an average night, an Il Vino busboy is supporting three servers, fifteen tables, and sixty diners at once. When attending to their sections, busboys are expected to be quick, attentive, and helpful.

Nightly, in addition to busing tables, the busboys sweep and mop the restaurant; clean the bathrooms; empty the garbage cans; wipe down tables and chairs; set the tables; stock the server stations with water glasses, dishes, napkins, straws, and silverware; stock the front bar with beer, liquor, and glassware; and set up the banquet room for any parties the next day. Because it is nearly impossible to accomplish all of this while being attentive to their sections, the busboys often do not finish their work until two hours after Il Vino has closed for the evening. After busing, cleaning, and setting up, which are considered the busboys' regular duties, they are responsible for performing a myriad of other occasional tasks. Busboys unclog toilets, clean up martini-induced vomit, change customers' flat tires, trap mice, organize storage rooms, move furniture, paint, salt the parking lot when it snows, water the plants, and scrape gum from the bottom of tables. In a pinch, they can also be counted on to cook, bartend, and perform minor first aid.

The busboys at Il Vino have not always had such a heavy workload. Over the years, they have slowly assumed responsibility for more and more tasks by doing "extra" work, which can be initiated by management or by the workers themselves. Roberto explains, "If you're my boss and you tell me, 'You know what, cut the lawn, arrange the flowers, all that,' I'll do it for you. And I'll do a good job, and moreover I'll do a little extra so that, 'Wow!' You come back and, 'Oh, you surprised me!'” (conversation with author, June 17, 2008). While extra work is a source of complaint when the immigrant workers are talking among themselves, there is universal agreement that complaining to management should be avoided. In fact, workers often respond promptly and with energy, if not enthusiasm, when called on to do extra tasks. They demonstrate their "willingness to work" by performing extra work without complaint and with alacrity. The workers even have a name for this performance - echándole ganas - which literally means "putting desire in it" but can be roughly translated as "putting effort into it" or "putting your back into it." The workers at Il Vino are very conscious of the impression they make and explain that they have important incentives for echándole ganas.

Many workers, like Alejandro, Leonardo, and Omar, acknowledge and resent that their "willingness to work hard" is promoted by their undocumented status. Leonardo says, "When you come from Mexico and you don't have anything, all you have to offer is that you are a good worker and you want to better yourself" (conversation with author, March 4, 2008). Omar agrees and says that, for undocumented workers, being pliant can make the difference between keeping or losing a job: "They know we are illegal, so if I complain, what do you think they will say to me? 'There's the door if you don't like it'” (conversation with author, July 16, 2008). Yet these workers also believe that having a good work ethic can reduce or even overcome the vulnerability associated with being undocumented. Leonardo continues, "If you're a good worker, nothing, not even being illegal, will ever affect you" (conversation with author, March 4, 2008). Roberto adds that working hard enhances income and security: "Our job is as a busboy, right, but we also do construction, organizing, throwing stuff out, cleaning.... They save money because they don't have to pay people to do [extra tasks]. But the other side of it is that it benefits us too, you know? In money, in more hours. Those are benefits" (conversation with author, June 16, 2008). Performing a willingness to work hard promotes these workers' financial stabilitya particularly important quality for undocumented people whose employment is frequently insecure and low paid.

Indeed, busboys receive both material and social inducements to work hard. The busboys earn tips from waiters and waitresses, who are more likely to tip generously when they are pleased with busboys' work performance. Tips are a significant component of the busboys' income: the busboys at Il Vino typically earn upward of one hundred dollars in tips alone on an average weekend night. This is a healthy supplement to their minimum-wage hourly pay. In addition to tips, the Mexican workers at Il Vino also receive considerable social esteem from their coworkers and managers, extending the benefits of working hard beyond economy and into the realm of autonomy and respect. For example, Rene observes that: "[The bosses] are always noticing who works and who doesn't work. And when you win them over, they don't watch you anymore, they give you - you win their respect" (conversation with author, July 13, 2008). As I explore in more depth later, gaining esteem for being a hard worker can enhance the dignity of undocumented immigrants who are highly stigmatized as "illegal aliens," while gaining autonomy and respect on the job may be particularly important for undocumented workers who are subject to constant and arbitrary supervision (see Romero 2002). ${ }^{7}$

Cultivating a reputation as hard workers has another important benefit: it can help undocumented workers carve out employment niches for themselves in the low-wage job market (see Tilly 1998 for a discussion of opportunity hoarding). When Alejandro arrived in the United States nearly 20 years ago, his father had promised to secure him a job in the restaurant where he worked as a cook. The "job" was washing dishes in the restaurant kitchen - for free. Alejandro explains that, "Just to get me a job [my dad] was like, 'Just try him out. If he works you can pay him, if not, then he'll learn.' They didn't pay me for the first month" (conversation with author, June 3, 2008). Twenty years later, Alejandro still works in restaurants. He has been a busboy, a busboy manager, and even a waiter during this time - and his calmness, seniority, and expertise have earned him the nickname "Buddha" among his friends. Alejandro has learned 
one thing well: he can capitalize on stereotypes about Mexican immigrants as hard workers to promote employment for himself and his friends. He describes one situation in particular, in which the popular pizza place where he worked had opened a second restaurant and hired a young, all-white bus staff:

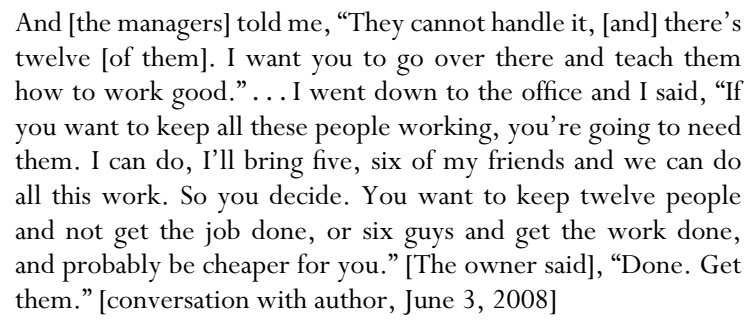

Alejandro wielded stereotypes of Mexican immigrants as particularly hard workers to persuade his boss to hire his friends. Recruiting acquaintances for job openings is a common practice among immigrant workers, whose employers are largely content to let workers take charge of the hiring and training process (see Waldinger and Lichter 2003; Zlolniski 2006). For Alejandro and his co-immigrant friends, a "willingness to work hard" is a special feature of their labor power that they can strategically draw on to make their labor more attractive to employers.

\section{"MOVE IT! MOVE IT! PUT SOME EFFORT INTO IT!": NEGOTIATING NORMS OF HARD WORK ON THE JOB}

Unlike the rest of the service staff, the busboys at Il Vino have no direct, formal manager. Instead, the most senior busboy is usually considered the de facto leader and is responsible for managing interactions between busboys and management staff. For the past ten years, Rene has been in this leadership position more often than anyone else. Rene is a quiet and good-humored man in his late twenties who is widely respected not only by the other busboys but also by the waitstaff, managers, and owners of Il Vino. Rene says that he does "not like to be the boss of anybody" (conversation with author, August 5, 2007) and prefers to lead by example; he can often be found in other busboys' sections, helping them serve water or clean tables. Rene is a highly motivated and efficient worker who often teases his coworkers over the walkie-talkie radios they carry. "Córrele, córrele!" or "Échale ganas!" he often tells them-_Move it, move it! Put some effort into it!].

The Mexican immigrant workers at Il Vino have several mechanisms through which they negotiate and enforce norms of hard work on the job, ranging from gentle teasing to outright confrontation. For these mechanisms to be effective, the workers must be committed to working as a team. The team-oriented organization of work for Il Vino busboys is encouraged by several factors, including the tendency of management to treat the workers as a homogeneous group, the system of tip distribution in which all busboys pool their tips and split them equally, and long-standing social ties among workers. Teamwork also has important benefits for workers: it is critical to getting their work done quickly and efficiently and diffuses stress by insulating individual group members and spreading responsibility and accountability throughout the group.

All of the immigrant busboys who work at Il Vino generally agree that having a team-oriented approach to work is the best quality that a busboy can have, while the worst busboys are those who act individualistically or who are bossy. As Roberto explains, even the so-called busboy leader is careful not to act bossy and to contribute his share to the workload: "Like for example if tomorrow is going to be really busy, 'Okay, you do this, you do this, I'll do this, you do this.' It's not just one person, no one person is going to come and say, 'Okay, I want-.' No. Everyone is equal, we discuss it, 'Yeah, okay, what do you think?' 'How about this?' Like that, 'Cool, let's get to work'” (conversation with author, July 17, 2007). But just working together is not enough; all busboys are expected to work at roughly the same level. Roberto explains: "When we work as a team, we all work together as though we were a motor and the cylinders are, 'toom, toom, toom.' But if just one is kind of fucked up, now you have to work more, and it's not fair that one guy is like that. And the complaints start, 'Hey man, what the fuck?'” (conversation with author, June 17, 2008). Slacking workers are not tolerated for long, and conformity to work norms is continually encouraged and enforced among the workers.

One of the primary mechanisms by which these workers encourage norms of hard work is the use of humor. New or slow workers are nicknamed "turtle" or "stupid" and teased about their poor work ethic. One worker known for moving a bit slower than the others was nicknamed "el Ferrari," and when the other guys wanted him to move faster, they would call over their walkie-talkie radios: "Hey Ferrari, vroom vroom vroooooom!" If a busboy's section appears dirty, or if a table needs water, another busboy might come to help him and say to the server, "Where's your busboy? You don't have a busboy tonight or what?" Teasing is particularly important for socializing new workers, who are often unaccustomed to such fast-paced work. Alejandro explains: "There was one guy, slow. Slow as a turtle.... And we would joke around, like, 'Come on, move, Turtle.' Everybody calls him names. If they take it as a joke, they start to fit in, like, 'Oh my god, they call me a turtle, so I'm going to try to speed up a little more'" (conversation with author, June 3, 2008).

Goading each other into working harder is not always successful, and if one busboy consistently works more slowly than the rest, the other workers will adopt more serious measures to deal with the problem. When the restaurant is busy, the senior busboys will cover for the slow workerthis keeps management from noticing weakness in the work of the group. But when they are cleaning or setting up, the busboys may slow down their own work, or even stop working entirely, until the slow worker catches up. This puts serious pressure on the weak busboy. If the situation 
still does not improve, a sit-down discussion with the slacking worker may be in order. Luis explains that, "Look, there is a time and place to say something. Like when we stay and have a drink after work, we'll tell him, 'Listen, man, you suck, you sucked tonight. Try to do better.' And among the Mexicans, we tell each other, right? ... We trust each other to say, 'Look, man, work harder, pick it up, okay?'” (conversation with author, March 28, 2008). In extreme cases, the busboys will stop covering for a slacking worker and allow his weakness to be exposed to management; this usually results in the weak busboy's dismissal. This is a last resort, however, and the workers prefer strategies that do not expose them to interference by management or risk the cohesion of their team.

\section{"WE WETBACKS ARE PEOPLE WHO LIKE TO WORK": CONSENT AND CONTRADICTION}

I have so far described why and how undocumented Mexican restaurant workers perform social identities as hard workers on the job, but an important question remains: How do workers reconcile this identity with their broader values and beliefs? A comprehensive discussion of this question is outside the scope of this article (but see Gomberg-Muñoz in press), but in this final ethnographic section I examine how this cohort perceives itself in relation to wider narratives about immigration, work, and achievement in the United States. In particular, I explore how these workers reproduce and resist stereotypes about Mexican immigrants as they struggle to maximize their dignity and self-esteem.

Scholars of migration have considered the ways in which transmigration itself shapes the attainment of dignity and esteem. For example, Jeffrey Cohen (2001) and Lynn Stephen (2007) have shown that transmigrant workers boost their social stature in communities of origin through remittances and participation in transnational projects (see also Smith 2006). One extension of this argument is that transmigrant workers decouple the performance of socially degraded work in the United States from their social identities, which are presumed to meaningfully reside in Mexico. Thus, Michael Piore has argued that:

\footnotetext{
The temporary character of the migration flow appears to create a sharp distinction between work, on the one hand, and the social identity of the worker, on the other. The individual's social identity is located in the place of origin, the home community . . From the perspective of the migrant, the work performed is essentially asocial: It is purely a means to an end. [1979:54]
}

But my research indicates that undocumented workers do not leave their social identities at the border, even when they view their stay as temporary. Rather, work and social life in the United States are interactive spaces in which identities as men, friends, fathers, husbands, boyfriends, Mexicans, and workers are negotiated and transformed. Remittances and transnational projects are instrumental in helping workers attain financial security and respect in Mexico, but creating social identities on job sites in the United States is also important: it is a critical feature of workers' person- hoods. But as they cultivate social identities, undocumented Mexican immigrants contend with pervasive stereotypes and profound stigmatization.

In recent years, highly publicized and polarizing debates about immigration have relegated perceptions of Mexican immigrants in the United States into two popular onedimensional types. ${ }^{8}$ The first stereotype can be identified as "Mexicans as illegal aliens." This conception of Mexican immigrants identifies them as iconic illegal aliens and stigmatizes them as lawless, unclean, and threatening interlopers who paradoxically steal jobs and leech public assistance (Coutin and Chock 1997; De Genova 2005; Massey et al. 2002; Suarez-Orozco and Suarez-Orozco 1995; Vila 2000). As the fodder of conservative cable-news shows, radio programs, and high-profile local political campaigns, this stereotype has wide popular currency (De Genova 2005; Golash-Boza 2009). As a result, Latin American immigrants in the United States have become especially vulnerable to social alienation, exploitation, harassment, and hate crimes (Pew Hispanic Center 2007; Suarez-Orozco and SuarezOrozco 1995; Urbina 2009). According to federal crime statistics, hate crimes against Latinos in the United States surged 40 percent between 2003 and 2007-a period of heightened anti-immigrant sentiment (Urbina 2009).

The second prevailing stereotype can be called "Mexicans as hard-working immigrants" (see also Heyman 2001). This conception of Mexican immigrants locates them in historical narratives of "America as a nation of immigrants" and "America as a land of opportunity." Mexican immigrants, even the undocumented, are portrayed as sympathetic figures who have earned a moral claim to U.S. citizenship by working hard to improve their lives just as generations before them have done (Coutin and Chock 1997). This stereotype emphasizes Mexican immigrants' religiosity, family orientation, and work ethic and is frequently promoted in immigrant rights discourses. ${ }^{9}$ My research suggests that both of these stereotypes- "Mexicans as illegal aliens" and "Mexicans as hard-working immigrants"continue to abound and are applied (sometimes simultaneously) to Mexican workers in restaurants like Il Vino.

It is within this context that undocumented Mexican immigrants in the United States make sense of who they are and what they are doing. But as Heyman points out, "identifications are not the same as identities" (2001:135), and workers develop complex and contradictory perceptions of themselves as they respond to external oppression, engage hegemonic narratives about immigration and "America," and construct social identities in the United States.

It should not be surprising that undocumented workers take pains to distance themselves from notions that they are lawless, threatening, or unclean. In fact, workers have sophisticated responses to this stereotype, in which they argue that they are victims, not perpetrators, of criminal behavior and that "dirty" labor requires bravery and stamina. In the following quote, Lalo expresses a widely held view 
that counters stereotypes of undocumented immigrants as criminal:

\begin{abstract}
Jumping the border, yes, it's a crime. But is it criminal? One thing is to kill, or steal something. Okay, I'm stealing something in the sense that I am on your land without permission, but I didn't come to kill, I didn't come to steal, I didn't come to hurt anyone. But they don't want to see it that way. So, yes, jumping the border, I know that I'm committing a crime, but it's not the same as if I work for you and you don't pay me. That is stealing. And we are human beings, and we should help each other. And you should pay me because I'm doing work for you. But you take advantage and don't pay me because I'm undocumented and I can't do anything about it. You just call immigration, or the police, and it's over. That's a robbery, any way you want to look at it. That's stealing, that's a crime. [conversation with author, August 1, 2007]
\end{abstract}

In this comment, Lalo not only reaffirms the image of the "hard-working Mexican" but also makes a moral argument against the abuse of undocumented labor. As the threat of immigration enforcement is ever present in the labor relations of undocumented workers, many workers like Lalo perceive such laws as tools in their exploitation (see also Heyman 2001; Zlolniski 2003). In fact, these workers are angry at the way that undocumented status makes them vulnerable to exploitation, as this comment from Alejandro shows: "The bosses know you don't have papers, and they use [that knowledge]. That's why they pay you what they pay you, because you cannot ask for more money" (conversation with author, June 3, 2008). In contrast to exploitative employers, undocumented workers emphasize that they have an ethical approach to getting ahead: good, old-fashioned hard work.

Undocumented workers valorize the integrity of hard work and draw strong boundaries against "suck-ups" (barberos) and U.S. workers, who they say will win the boss at any cost. ${ }^{10}$ Rene explains, “I don't work hard to kiss ass. I don't want to be like, 'Look, boss, let me clean your shoes, let me do this,' you know? I just go to work, do my job, go home. American workers are like, 'How are you, boss? A chair, boss? A soda, boss?' ... That's why I don't walk around kissing ass. I want respect at my job" (conversation with author, August 5, 2007).

These workers also associate dirty and difficult labor with bravery and self-worth. Luis says, "I think that an American is not worth as much as a Mexican, he doesn't work the same as a Mexican. It's like I told you, a Mexican takes risks and an American, if he sees that something is difficult or a job is dangerous, he won't do it ... I think that's why the boss would rather hire illegals than Americans" (conversation with author, March 28, 2008). Emphasizing the idea that Mexican workers have an ethical approach to getting ahead renders hard work a moral activity that is worthy of dignity and respect. By equating willingness to work with integrity and bravery, workers convert socially degraded work into a source of self-esteem.

Undocumented Mexican workers have very high laborforce participation rates, and these workers attribute their employment opportunities to a combination of personal strengths and opportunity in the United States. ${ }^{11}$ This comment from Leonardo shows how he situates "Mexican work ethic" in a narrative about opportunity in the United States: "We wetbacks are people who like to work and ... to improve ourselves.... And when a Mexican comes here illegally and there are good opportunities, he will take advantage of them and improve himself" (conversation with author, March 4, 2008). Ironically, their very exclusion from the polity as undocumented immigrants supports a belief in "American" achievement ideology because the structural limitations these workers encounter are explained by their illegal status. For example, Lalo claims: "If I had papers, I would never be without work. But how many white guys do you see begging on the street corner who are strong, capable of working in a kitchen.... Why don't they work? They're lazy" (conversation with author, July 17, 2007). That is, to the extent that these workers experience exclusion from opportunities in the United States, they believe that they are excluded because they are not actually U.S. citizens. In spite of their resentment toward the ways in which undocumented status constrains their opportunities, these workers widely affirm a belief in "America as a land of opportunity."

Cultivating a social identity as hard workers creates other contradictions for immigrant workers. For example, while they perform a willingness to work, they are reluctant to see themselves as deferential. In fact, they develop narratives that emphasize Mexican workers' physical bravery and resistance to abusive treatment. When these workers sit around together and have a beer, they relish telling "war stories" in which a Mexican worker heroically confronts an abusive boss. Like most war stories, these are probably exaggerated. Nevertheless, narratives about standing up to the boss, challenging him physically, and putting one's job at risk highlight workers' self-respect and reveal that their "willingness to work" has its limits.

These limits are particularly revealed when workers discuss their plans for the future: Alejandro, Rene, Chuy, Manuel, and Luis have all (unprompted) expressed a desire to get a union job. Tellingly, they state their goal as "getting a union job," as opposed to work as a union carpenter or brick-layer or electrician, indicating that they are at least as concerned about being part of a union collective as they are about the work itself. For Rene, whose knowledge about union work is mostly derived from his electrician brotherin-law, the appeal of being in a union has as much to do with autonomy as job security. He explains that, "If I get a job with the union, then when somebody asks, 'Where do you work?' I can tell them, 'Oh, I'm Local 399,' instead of 'I work for this guy or that guy.' Then you don't belong to anybody, it's more of a professional job" (conversation with author, July 13, 2008). Workers' goals of unionization suggest that, under different circumstances, these "willing workers" might not be so different from more politicized immigrants described elsewhere (e.g., Brodkin 2007; SmithNonini 2007; Zlolniski 2003, 2006). 
Cultivating a social identity as hard workers provides several short-term advantages for undocumented Mexican workers, including control over the composition and organization of their work group and a measure of financial stability and social esteem. Yet a reputation as hard workers also has long-term implications for undocumented Mexican workers. In the long run, reiterating racial stereotypes about Mexicans' putatively superior work ethic can reproduce their subordination, maintain categorical differentiation of the working class, and even set up the "hard workers" themselves for intensified exploitation (see also De Genova 2005; Tilly 1998; Willis 1977).

\section{CONCLUSION: VULNERABILITY AND AGENCY}

In the introduction to this article, I posed a question: Why would presumably permanent members of the low-wage labor force put so much effort into being hard workers? Part of the answer is related to political processes that create and maintain conditions of vulnerability vis-à-vis the capitalist state (De Genova 2005; Portes and Walton 1981; Sassen 1988). In the United States, a combination of border militarization and anti-immigrant policies has not reduced the flow of labor migration but, rather, has "illegalized" it, legitimizing exploitation of immigrant workers by making access to political, economic, and social resources a right of citizenship (De Genova 2005; Massey et al. 2002; Ngai 2005). National boundaries and immigration policies produce, reinforce, and reify the distinctions among "citizen," "legal immigrant," and "illegal alien" (Heyman 2001; Ngai 2005; Sassen 1988). Selective enforcement of the border and the globalization of all aspects of production except for labor renders persistent labor migration all but certain (Massey et al. 2002; Portes and Walton 1981). Thus, immigration policies do not stop labor migration; rather, they generate inequality among the labor force by assigning illegal status to a segment of the working class (Heyman 2001; Lipsitz 2005; Sassen-Koob 1981).

While the workers featured in this ethnography feel the impact of these policies acutely, they are not mere pawns of capitalist forces. Rather, they are workers who take an active role in cultivating well-being by negotiating norms of efficiency, self-motivation, and "willingness" at their U.S. jobsites. While this process has the benefit of making these workers more attractive to low-wage employers, it has the side effect of reproducing various exploitative aspects of their work, including intensification of their labor characterized by increasing workloads for the same pay.

Undocumented Mexican workers in the United States do not arrive freely able to position themselves as they choose in relation to U.S. social structure. Instead, they contend with powerful stereotypes and negotiate their identity and self-worth within these subjective constraints. While these workers are not immune either from the stigma of being "illegal aliens" or the stigma of doing "dirty work," they do not necessarily internalize these stigmatizations. In fact, they develop multiple and various strategies for protecting themselves psychologically and defending their dignity and self-esteem.

Undocumented workers are neither mere victims or criminals, nor inherently hard workers or liberated actors free from the constraints of nation-state boundaries or hegemonies. They are complicated people who actively and creatively engage in workaday struggles to make their lives better. As they contend with racial, legal, and class constraints, they cultivate financial and emotional well-being by developing social identities as hard workers who are worthy of dignity and respect. By establishing reputations as good workers, they maintain markets for their labor and sequester job opportunities for themselves and members of their social networks. Moreover, they cultivate an identity that is consistent with their values and resistant to the stigma associated with illegal immigration.

Ruth Gomberg-Muñoz Department of Anthropology, University of Illinois at Chicago, Chicago, IL 60607

\section{NOTES}

Acknowledgments. I am very grateful to all of the ethnographic participants who contributed to this research. I am also indebted to Molly Doane, Josiah Heyman, Tom Boellstorff, and the anonymous $A A$ reviewers, all of whom read this manuscript and offered valuable insights and suggestions. This material is based on work supported by the National Science Foundation under Grant No. 0718696.

1. These workers are real people — not composites — and I have changed all names, nicknames, and identifying details of people and places to protect their anonymity. While there are many large-scale restaurants in the Chicago area that could easily fit Il Vino's description, the establishment that I describe here is a fictitious composite of several different restaurants. I have tried to capture the scale, pace, economy, and culture of the real-life restaurant where most of these men work or have worked, but the details have all been changed. Most ethnographic data collection took place between August of 2007 and January of 2009. Interviews with immigrant workers were conducted in Spanish except for those with Alejandro, who prefers English. Interviews with immigrants' coworkers and managers were all conducted in English.

2. Scholars can choose from several different words to describe foreign-born workers in the United States, including immigrant, migrant, transmigrant, and transborder (see De Genova 2005 and Stephen 2007). Each term addresses a particular nuance in the relationship of mobile workers to the nationstate, and each has its own merits and drawbacks. I use the term immigrant when I describe my ethnographic participants for two related reasons. First, many of them are long-term, if not permanent, settlers in the United States, and migrant and transmigrant suggest an element of mobility or impermanence that does not accurately reflect their situations. Second, my research focuses on workers' daily activities in Chicago and less on their transnational and migration experiences per se. I 
use transmigrant when referring to transnationalist scholarship or transnational workers generally.

3. As is typical in high-end restaurants, the bus staff at Il Vino is all male. Mexican immigrant women have lower labor-force participation rates than their male counterparts and, when employed, tend to be concentrated in the lowest-paying jobs and in private households (Hondagneu-Sotelo 1994, 2001; Mehta et al. 2002).

4. The state of Guanajuato is part of a region known as the Bajío, an area of Mexico that has the distinction of being populous and well-integrated in national and international markets. Migration of Bajío workers to the United States is more than a century old; it began in earnest during the early 20th century, accelerated in midcentury, and continues today. There are long-standing webs of transnational networks between the Bajío region of Mexico and the United States; many of the workers featured here are second- and even third-generation transmigrants. For more on the Bajío as a "sending" region, see Arias 2004; Cornelius 1989; Massey et al. 2002. For more on transnational social networks, see Alvarez 2005; Basch et al. 1994; Guarnizo and Smith 1999; Cordero-Guzman et al. 2001; Smith 2006.

5. I am indebted to anonymous reviewer \#4 for proposing this objection.

6. This is a simple conception of structure, culture, and agency that will undoubtedly fail to satisfy some scholars who are concerned with more nuanced considerations of each term. For more developed theoretical discussions of the interaction of structure, culture, and agency, see Giddens 1993, Ortner 2006, and Sewell 1992.

7. Of course, being esteemed for being a hard worker and being stigmatized are not contradictory. Gutierrez (1995) points out that the fodder of negative stereotypes about Mexicansdocility, tractability, uncleanliness - came to be seen as great virtues of a low-wage labor force in the United States. During U.S. immigration hearings of the early 20th century, Mexicans were repeatedly identified as a labor force whose racial characteristics made them ideally suited for arduous and low-paying work (Gutierrez 1995; Pedraza and Rumbaut 1996).

8. It is important to note that these stereotypes - and, in Chicago, the term Mexican as well-not only apply to workers from Mexico but also to immigrants from Latin America generally. When Latin American immigrants come to the United States, they are ascribed into the racial category of "Latino" or "Hispanic" that subsumes actual regional, class, ethnic, and national differences (Omi and Winant 1994; Portes and Rumbaut 1996). Because of the large Mexican population in Chicago, Latin American workers are often referred to as "Mexican," regardless of their actual national origin.

9. The "work ethic" of Latin American immigrants is often invoked to contrast them with African American workers, reinforcing racist stereotypes and economic marginalization of both groups but to the particular detriment of the latter (see Steinberg 2005; Waldinger and Lichter 2003).
10. These workers frequently conflate "American" with "white." Because of intense racial segregation of African Americans in the Chicago area, these workers have very little contact with African Americans and do not tend to see them as competitors in the labor market.

11. The labor-force participation rate of undocumented Latino immigrants in the Chicago area is estimated to be 90 percent, compared to 69 percent for the total metro-area population (Mehta et al. 2002). Nationally, the labor-force participation rate for undocumented immigrant men is estimated to be 94 percent, compared with 83 percent for U.S.-born men (Passel and Cohn 2009).

\section{REFERENCES CITED}

Adler, Rachel

2005 Oye Comprade! The Chef Needs a Dishwasher: Yucatecan Men in the Dallas Restaurant Economy. Urban Anthropology 34(2-3):217-246.

Alvarez, Robert

2005 Mangos, Chiles, and Truckers: The Business of Transnationalism. Minneapolis: University of Minnesota Press.

Appadurai, Arjun

1996 Modernity at Large: Cultural Dimensions of Globalization. Minneapolis: University of Minnesota Press.

2004 The Capacity to Aspire: Culture and the Terms of Recognition. In Culture and Public Action. Vijayendra Rao and Michael Walton, eds. Pp. 59-84. Delhi: Permanent Black.

Arias, Patricia

2004 Old Paradigms and New Scenarios in a Migratory Tradition: U.S. Migration from Guanajuato. In Crossing the Border: Research from the Mexican Migration Project. Jorge Durand and Douglas Massey, eds. Pp. 171-183. New York: Russell Sage Foundation.

Basch, Linda, Nina Glick Schiller, and Cristina Szanton Blanc

1994 Nations Unbound: Transnational Projects, Postcolonial Predicaments, and Deterritorialized Nation-States.

Amsterdam: Gordon and Breach Science Publishers.

Bourgois, Philippe

2003[1996] In Search of Respect: Selling Crack in El Barrio. 2nd edition. New York: Cambridge University Press.

Brodkin, Karen

2007 Making Democracy Matter: Identity and Activism in Los

Angeles. New Brunswick, NJ: Rutgers University Press.

Calavita, Kitty

1994 U.S. Immigration and Policy Responses: The Limits of Legislation. In Controlling Immigration. Wayne Cornelius, Philip Martin, and James Hollifield, eds. Pp. 55-82. Stanford: Stanford University Press.

Castells, Manuel

2000[1996] The Rise of the Network Society. 2nd edition. Malden, MA: Blackwell Publishing.

Chavez, Leo R.

1992 Shadowed Lives: Undocumented Immigrants in American Society. New York: Wadsworth. 
Cohen, Jeffrey $\mathrm{H}$.

2001 Transnational Migration in Rural Oaxaca, Mexico: Dependency, Development, and the Household. American Anthropologist 103(4):954-967.

Cordero-Guzman, Hector, Robert C. Smith, and Ramon Grosfoguel, eds.

2001 Migration, Transnationalization, and Race in a Changing New York. Philadelphia, PA: Temple University Press.

Cornelius, Wayne

1989 Impacts of the 1986 U.S. Immigration Law on Emigration from Rural Mexican Sending Communities. Population and Development Review 15:689-705.

Coutin, Susan Bibler, and Phyllis Pease Chock

1997 "Your Friend, the Illegal": Definition and Paradox in Newspaper Accounts of U.S. Immigration Reform. Identities 2(12):123-148.

De Genova, Nicholas

2005 Working the Boundaries: Race, Space, and "Illegality" in Mexican Chicago. Durham, NC: Duke University Press.

De Genova, Nicholas, and Ana Y. Ramos-Zayas

2003 Latino Crossings: Mexicans, Puerto Ricans, and the Politics of Race and Citizenship. New York: Routledge.

di Leonardo, Micaela

1998 Exotics at Home: Anthropologies, Others, and American Modernity. Chicago: University of Chicago Press.

Douglas, Mary

2004 Traditional Culture - Let's Hear No More about It. In Culture and Public Action. Vijayendra Rao and Michael Walton, eds. Pp. 85-109. Delhi: Permanent Black.

Durrenberger, E. Paul, and Suzan Erem

2005 Class Acts: An Anthropology of Service Workers and Their Union. Boulder: Paradigm Press.

Fernandez-Kelly, Maria Patricia

1983 For We Are Sold, I and My People: Women and Industry in Mexico's Frontier. Albany: University of New York Press.

Fine, Gary Alan

1996 Kitchens: The Culture of Restaurant Work. Berkeley: University of California Press.

Gamio, Manuel

1971[1930] Mexican Immigration to the United States: A Study of Human Migration and Adjustment. New York: Dover.

Gershon, Ilana, and Janelle S. Taylor

2008 Introduction to "In Focus: Culture in the Spaces of No Culture.” American Anthropologist 110(4):417-421.

Gibson-Graham, J. K.

1996 The End of Capitalism (As We Knew It): A Feminist Critique of Political Economy. Minneapolis: University of Minnesota Press.

Giddens, Anthony

1993 Problems of Action and Structure. In The Giddens Reader. Philip Cassell, ed. Pp. 88-175. Stanford: Stanford University Press.

Goffman, Erving

1959 The Presentation of Self in Everyday Life. New York: Anchor.

Golash-Boza, Tanya

2009 A Confluence of Interests in Immigration Enforcement:
How Politicians, the Media, and Corporations Profit from Immigration Policies Destined to Fail. Sociology Compass 3:293294.

Gomberg-Muñoz, Ruth

In press Labor and Legality: Life in a Mexican Immigrant Network. New York: Oxford University Press.

Gray, Mia

2004 The Social Construction of the Service Sector: Institutional Structures and Labour Market Outcomes. Geoforum 35:2334.

Guarnizo, Luis Eduardo, and Michael Peter Smith 1998 The Locations of Transnationalism. In Transnationalism from Below. Michael Peter Smith and Luis Eduardo Guarnizo, eds. Pp. 3-34. New Brunswick, NJ: Transaction.

Gunewardena, Nandini, and Ann Kingsolver

2007 Introduction. In The Gender of Globalization: Women Navigating Cultural and Economic Marginalization. Nandini Gunewardena and Ann Kingsolver, eds. Pp. 321. Santa Fe, NM: School for Advanced Research Press.

Gupta, Akhil, and James Ferguson

1997 Discipline and Practice: "The Field" as Site, Method, and Location in Anthropology. In Anthropological Locations: Boundaries and Grounds of a Field Science. Akhil Gupta and James Ferguson, eds. Pp. 1-46. Berkeley: University of California Press.

Gutierrez, David G.

1995 Walls and Mirrors: Mexican Americans, Mexican Immigrants, and the Politics of Ethnicity. Berkeley: University of California Press.

Heyman, Josiah McC.

1998 State Effects on Labor Exploitation: The INS and Undocumented Immigrants at the Mexico-United States Border. Critique of Anthropology 18(2):157-180.

2001 Class and Classification at the U.S.-Mexico Border. Human Organization 60(2):128-140.

Hondagneu-Sotelo, Pierrette

1994 Gendered Transitions: Mexican Experiences of Immigration. Berkeley: University of California Press.

2001 Doméstica: Immigrant Workers Cleaning and Caring in the Shadows of Affluence. Berkeley: University of California Press.

Kearney, Michael

2004 The Classifying and Value-Filtering Missions of Borders. Anthropological Theory 4(2):131-156.

Lamphere, Louise, Alex Stepick, and Guillermo Grenier

1994 Introduction. In Newcomers in the Workplace: Immigrants and the Restructuring of the U.S. Economy. Louise Lamphere, Alex Stepick, and Guillermo Grenier, eds. Pp. 1-21. Philadelphia, PA: Temple University Press.

Lipsitz, George

2005 Foreword. In Mangos, Chiles and Truckers: The Business of Transnationalism. Minneapolis: University of Minnesota Press. Mahler, Sarah J.

1998 Theoretical and Empirical Contributions toward a Research Agenda for Transnationalism. In Transnationalism from Below. 
Michael Peter Smith and Luis Eduardo Guarnizo, eds. Pp. 64 102. New Brunswick, NJ: Transaction Publishers.

Marx, Karl

1973[1852] The Eighteenth Brumaire of Louis Bonaparte. In Political Writings, vol. 2: Surveys from Exile. David Fernbach, ed. Pp. 143-249. New York: Penguin Books.

Massey, Douglas, Joaquin Arango, Graeme Hugo, Ali Kouaouchi, Adela Pellegrino, and J. Edward Taylor

1994 An Evaluation of International Migration Theory: The North

American Case. Population and Development Review 20:699751.

Massey, Douglas, Jorge Durand, and Nolan J. Malone

2002 Beyond Smoke and Mirrors: Mexican Immigration in an Era of Economic Integration. New York: Russell Sage Foundation.

Mehta, Chirag, Nik Theodore, Iliana Mora, and Jennifer Wade 2002 Chicago's Undocumented Immigrants: An Analysis of Wages, Working Conditions, and Economic Contributions. Chicago: UIC Center for Urban Economic Development.

Moss, Philip, and Chris Tilly

2001 Stories Employers Tell: Race, Skill, and Hiring in America.

New York: Russell Sage Foundation.

Neckerman, Kathryn, and Joleen Kirschenman

1991 Hiring Strategies, Racial Bias, and Inner City Workers. Social Problems 38(4):433-447.

Ngai, Mae

2005 Impossible Subjects: Illegal Aliens and the Making of Modern

America. Princeton: Princeton University Press.

Omi, Michael, and Howard Winant

1994 Racial Formation in the United States from the 1960s to the 1990s. New York: Routledge.

Ortner, Sherry

1997 Thick Resistance: Death and the Cultural Construction of Agency in Himalayan Mountaineering. Special issue, "The Fate of 'Culture': Geertz and Beyond,” Representations 59:135162.

2006 Anthropology and Social Theory: Culture, Power, and the Acting Subject. Durham, NC: Duke University Press.

Passel, Jeffrey

2006 Size and Characteristics of the Unauthorized Migrant Popu-

lation in the U.S. Estimates Based on the March 2005 Current

Population Survey. Washington, DC: Pew Hispanic Center. http: / / pewhispanic.org/reports/report.php?ReportID=61, accessed November 1, 2009.

Passel, Jeffrey, and D'Vera Cohn

2009 A Portrait of Unauthorized Immigration in the United States.

Washington, DC: Pew Hispanic Center. http: / / pewhispanic. org/files/reports/107.pdf, accessed August 13, 2009.

Pedraza, Silvia, and Ruben G. Rumbaut

1996 Origins and Destinies: Immigration, Race, and Ethnicity in

America. New York: Wadsworth.

Pew Hispanic Center

2007 National Survey of Latinos: As Illegal Immigration Issue Heats Up, Hispanics Feel a Chill. http://pewhispanic.org/ reports/report.php?ReportID $=84$, accessed December 12, 2008.
Piore, Michael

1979 Birds of Passage: Migrant Labor and Industrial Societies. New York: Cambridge University Press.

Portes, Alejandro, and Ruben Rumbaut

1996 Immigrant America: A Portrait. Berkeley: University of California Press.

Portes, Alejandro, and John Walton

1981 Labor, Class, and the International System. New York: Academic Press.

Rao, Vijayendra, and Michael Walton

2004 Culture and Public Action: Relationality, Equality of Agency, and Development. In Culture and Public Action. Vijayendra Rao and Michael Walton, eds. Pp. 3-36. Delhi: Permanent Black.

Ready, Timothy, and Allert Brown-Gort

2005 The State of Latino Chicago: This Is Home Now. South Bend: Institute for Latino Studies, University of Notre Dame. http: / / latinostudies.nd.edu/pubs/pubs/StateofLatino-final.pdf, accessed July 10, 2007.

Romero, Mary

2002 Maid in the U.S.A. New York: Routledge.

Rosenblatt, Daniel

2004 An Anthropology Made Safe for Culture: Patterns of Practice and the Politics of Difference in Ruth Benedict. American Anthropologist 106(3):459-472.

Sassen, Saskia

1988 The Mobility of Labor and Capital: A Study in International Investment and Labor Flow. Cambridge: Cambridge University Press.

Sassen-Koob, Saskia

1981 Towards a Conceptualization of Immigrant Labor. Social Problems 29(1):65-85.

Sen, Amartya

2004 How Does Culture Matter? In Culture and Public Action. Vijayendra Rao and Michael Walton, eds. Pp. 37-58. Delhi: Permanent Black.

Sewell, William H.

1992 A Theory of Structure: Duality, Agency, and Transformation. The American Journal of Sociology 98(1):1-29.

Smith, Robert C.

2006 Mexican New York: Transnational Lives of New Immigrants. Berkeley: University of California Press.

Smith-Nonini, Sandy

2007 Sticking to the Union: Anthropologists and "Union Maids" in San Francisco. In The Gender of Globalization: Women Navigating Cultural and Economic Marginalization. Nandini Gunewardena and Ann Kingsolver, eds. Pp. 197-214. Santa Fe, NM: School for Advanced Research Press.

Steinberg, Stephen

2005 Immigration, African Americans, and Race Discourse. New Politics 10(3). http://www.wpunj.edu/ newpol/issue39/ Steinberg39.htm, accessed August 13, 2009.

Stephen, Lynn

2007 Transborder Lives: Indigenous Oaxacans in Mexico, California, and Oregon. Durham, NC: Duke University Press. 
Stepick, Alex, and Guillermo Grenier, with Hafidh A. Hafidh, Sue Chaffee, and Debbie Draznin

1994 The View from the Back of the House: Restaurants and Hotels in Miami. In Newcomers in the Workplace: Immigrants and the Restructuring of the U.S. Economy. Louise Lamphere, Alex Stepick, and Guillermo Grenier, eds. Pp. 181198. Philadelphia, PA: Temple University Press.

Suarez-Orozco, Carola, and Marcelo Suarez-Orozco

1995 Transformations: Immigration, Family Life, and Achievement Motivation among Latino Adolescents. Stanford: University of Stanford Press.

Tilly, Charles

1998 Durable Inequality. Berkeley: University of California Press.

Urbina, Ian

2009 After Pennsylvania Trial, Tensions Simmer over Race. New York Times, May 16: A18.

Vila, Pablo

2000 Crossing Borders, Reinforcing Borders: Social Categories, Metaphors, and Narrative Identities on the U.S.-Mexico Frontier. Austin: University of Texas Press.

Waldinger, Roger, and Michael Lichter

2003 How the Other Half Works: Immigration and the Social Organization of Labor. Berkeley: University of California Press.

Willis, Paul

1977 Learning to Labor: How Working Class Kids Get WorkingClass Jobs. New York: Columbia University Press.

Zlolniski, Christian

2003 Labor Control and Resistance of Mexican Immigrant Janitors in Silicon Valley. Human Organization 62(1):39-49.
2006 Janitors, Street Vendors, and Activists: The Lives of Mexican Immigrants in Silicon Valley. Berkeley: University of California Press.

\section{FOR FURTHER READING}

(These selections were made by the American Anthropologist editorial interns as examples of research related in some way to this article. They do not necessarily reflect the views of the author.)

Cahn, Peter S.

2006 Building down and Dreaming up. American Ethnologist 33(1):126-142.

DeLuca, Laura

2009 Transnational Migration, the Lost Girls of Sudan and Global "Care Work": A Photo Essay. Anthropology of Work Review 30(1):13-15.

Feltault, Kelly

2005 "We're Our Own Boss": Gendered Class-Consciousness and White Privilege among Hooper's Island Crab Pickers. Anthropology of Work Review 26(1):1-13.

Striffler, Steve

2007 Neither Here nor There: Mexican Immigrant Workers and the Search for Home. American Ethnologist 34(4):674-688.

Urciuoli, Bonnie

2008 Skills and Selves in the New Workplace. American Ethnologist 35(2):211-228.

Wortham, Stanton, Katherine Mortimer, and Elaine Allard 2009 Mexicans as Model Minorities in the New Latino Diaspora. Anthropology and Education Quarterly 40(4):388-404. 